\title{
IMPACT OF INFLATION ON INFRASTRUCTURAL INVESTMENT IN NIGERIA
}

\author{
Onyeka, Virginia Nnenna \\ Department of Accountancy \\ Enugu State University of Science and Technology (ESUT) \\ Enugu, Nigeria
}

\begin{abstract}
Inflation affects both the private and government sectors as well as individuals. It triggers prices if not properly managed and reduces the zeal for investment; an investment is an indispensable aspect of any economy. It is therefore against the effect of inflation on the economy that our paper examined the impact of inflation on infrastructural investment in Nigeria. Our result showed that the impact of inflation rate on infrastructural investment was negative and significant in Nigeria. We therefore, recommend that government should stick to prudent economic policies avoid excessive money printing which inflation targeting would achieved via price stabilization and also promote investment climate in Nigeria.
\end{abstract}

Keywords: Inflation, Infrastructural Investment, Gross Domestic Product, Nigeria

\section{Introduction}

Inflation affects both the private and government sectors as well as individuals. It triggers prices if not properly managed and reduces the zeal for investment; an investment is an indispensable aspect of any economy. The effect of inflation on investments occurs directly and indirectly. Inflation increases transactions and information cost which inhibits economic growth and development. For example, when inflation makes nominal values uncertain, investment planning becomes difficult. Individuals may be reluctant to enter into contracts when inflations cannot be predicted, making relative prices uncertain. This reluctance to enter into contract over time will inhibit investment which will affect economic growth and result in financial recession (Hellerstein, 1997). The problem should not be over emphasized as it is a monster in the growth of any economy and investment environment. Due to the fact that this challenge affect return on investment, discourages savings and inhibit growth of the Nigerian economy. So in unraveling the problems of inflation on investments and Gross Domestic Product (GDP), this study will assess the causes and effects of living standards, as well as proffering possible solutions and advice that would impact positively on investment.

Economists tend to emphasize that inflation can do economic damage by distorting investments and consumption decisions. Distortions result first from households and business uncertainty about inflation's future course, and second from inflation's interaction with the Nigerian tax code. Distortion in economic activity also may result from the uncertainty that arises about inflation's future course. When inflation is stable, people are more likely to have roughly the same anticipation of its future level. When inflation is highly volatile, however, but has different guesses. Most turn out to be wrong. Inadvertently some end up winners and others losers. This occurs whether inflation's level goes up or down. Once inflation has become embedded in economic behaviour, it has been quite difficult to remove its influence.

A key insight of the recent theories is that inflation exacerbates so-called frictions in credit markets. In smoothly operating credit markets, banks can easily adjust nominal interest rates when they need to, but frictions create obstacles that make this adjustment difficult. Government ceilings on interest rates are an example of such an obstacle. Obstacles can also arise from the actions of banks themselves, when they respond in the best possible way to the incentives and risks that are created by existing laws, regulations, policies, and economic conditions. Since empirical studies have shown that credit market frictions are more severe in developing countries than developed countries, these frictions may play an important role in explaining the impact inflation has on investment in these countries.

One way, inflation might affect investment hence economic growth through the banking sector is by reducing the overall amount of credit that is available to businesses. The story goes something like this. Higher inflation can decrease the real rate of return on assets. Lower real rates of return discourage saving but encourage borrowing. At this point, new borrowers entering the market are likely to be of lesser quality and are more likely to default on their loans. Banks may react to the combined effects of lower real returns on their loans and the influx of riskier borrowers by rationing credit. That is, if banks find it difficult to differentiate between good and bad borrowers, they may refuse to make loans, or they may at least restrict the quantity of loans made. Simply charging a higher nominal interest rate on loans merely makes the problem worse because it causes low risk borrowers to exit the market. And in those countries with government imposed usury laws or interest rate ceilings, increasing the nominal interest rate may not be possible.

Whatever the cause, when financial intermediaries ration credit in this way, the result is lower investment in the economy, thus with lower investment, the present and future productivity of the economy tends to suffer. This, in turn, lowers real economic activity. But there is something peculiar about the effect of inflation on the financial sector: It appears to have important thresholds. Only when inflation rises above some critical level does rationing occur. At very low rates of inflation, inflation does not cause credit rationing. This implies that beneath some threshold, higher inflation might actually lead to increased real economic activity.

Some recent studies have found cross-country evidence supporting the view that long -term growth is adversely affected by inflation (Kormendi and Meguire 1985; Fischer 1983, 1991, 1993; De Gregorio 1993; Gylfason 1991; Roubini and Salai-Martin 1992; Grier and Tullock 1989; Levine and Zervos 1992). Countries (especially in Latin America) that have experienced high inflation rates, have also witnessed lower long-term growth (Cardoso and Fishlow 1989; De Gregorio 
1992a, 1992b). This literature is part of the endogenous growth literature, which tries to determine the causes of differences in growth rates in different countries.

There is now considerable evidence that investment is one of the most important determinants of long-term growth (Barro 1991; Levine and Renelt 1992). It has often been suggested that a stable macroeconomic environment promotes growth by providing a more conducive environment for private investment. This issue has been directly addressed in the growth literature in the work by Fischer (1991, 1993); Easterly and Rebelo (1993); Frenkel and Khan (1990); and Bleaney (1996). Among the reasons why high inflation is likely to be adverse for growth are: economies that are not fully adjusted to a given rate of inflation usually suffer from relative price distortions caused by inflation. Nominal interest rates are often controlled, and hence real interest rates become negative and volatile thereby discouraging savings.

Depreciation of exchange rates lag behind inflation, resulting in variability in real appreciations and exchange rates; real tax collections do not keep up with inflation, because collections are based on nominal incomes of an earlier year (the Tanzi effect) and public utility prices are not raised in line with inflation. For both reasons, the fiscal problem is intensified by inflation, and public savings may be reduced. This may adversely affect public investment and high inflation is unstable. There is uncertainty about future rates of inflation, which reduces the efficiency of investment and discourages potential investors.

The effect of macroeconomic instability on growth comes largely from the effect of uncertainty on private investment. Multicountry panel data studies on investment report that measures of macroeconomic instability, like the variability in the real exchange rate or the rate of inflation, have an adverse impact on investment (Serven and Solimano 1992). In a study of 17 countries, Cordon (1990) finds that although there are outliers, evidence generally supports the view that high growth is associated with low inflation. This is suggested both by cross-country evidence and comparison over time for countries where the rate of growth has fallen in relation to an increased as the rate of inflation.

Fischer (1993) examines the role of macroeconomic factors in growth. He found evidence that growth is negatively associated with inflation and positively associated with good fiscal performance and undistorted foreign exchange markets. Growth may be linked to uncertainty and macroeconomic instability where temporary uncertainty about the macro-economy causes potential investors to wait for its resolution, thereby reducing the investment rate (Pindyck and Solimano 1993). Uncertainty and macroeconomic stability are, however, difficult to quantify. Fischer suggests that, since there are no good arguments for very high rates of inflation, a government that is producing high inflation is a government that has lost control. The inflation rate thus serves as an indicator of macroeconomic stability and the overall ability of the government to manage the economy.

Fischer found support for the view that a stable macroeconomic environment, meaning a reasonably low rate of inflation, a small budget deficit and an undistorted foreign exchange market, is conducive to sustained economic growth. He presents a growth accounting framework in which he identifies the main channels through which inflation reduces growth. He suggests that the variability of inflation might serve as a more direct indicator of the uncertainty of the macroeconomic environment. However, he finds it difficult to separate the level of inflation from the uncertainty about inflation, in terms of their effect on growth. This is because the inflation rate and its variance are highly correlated in cross-country data. Evidence is in favour of the view that macroeconomic stability, as measured by the inverse of the inflation rate and the indicators of macroeconomic trends, is associated with higher growth.

A good number of factors have been identified as the causes of inflation in Nigeria, which according to Nwankwo (1981) they includes excess demands, rising cost of production, limiting outputs and increasing money supply. People's immediate concern is with how their income holds up with changes in their expenses. Businesses care about how the prices of their product do in relation to their cost. Also government battle with polices to keep inflation rate at the barest minimum and ensure effective and efficient administration. It is therefore against these arguments that our paper examines the impact of inflation on infrastructural investment in Nigeria. The remainder of this paper is divided as follows. Section two contains our methodology. In section three, we present the result of our analysis and lastly in section four, we conclude and recommend.

\section{$2.0 \quad$ Methodology}

Our aim in this paper is to provide information that would enable policy makers in Nigeria and other developing economies on the need to diversify their investment portfolio in sectors that would reduce government expenditures in the future. Data for analysis were obtained from the Central Bank of Nigeria Statistical Bulletin for the period 1987 to 2011.

According to Gokal and Hanif (2004), several different economic theories has led to a consensus on the inflation - growth relationship. However, their study revealed that a weak negative correlation exists between inflation and growth, while the change in output gap bears significant bearing. The causality between the two variables ran one-way from GDP growth to inflation.

Moshi and Kilindo (1999) posit that Government policies are critical in determining the rate of economic growth, the levels of private investment and the magnitude of credit to the private sector. In studying private investment in Tanzania they assumed that certain variables will be the major determinants. These are government expenditure on investment, the exchange rate, GDP growth and capital inflows. These variables were incorporated in modeling private investment and their linear and non-linear relationships were analyzed. The results obtained lead to the conclusions that public investment-especially on infrastructure-exerts a positive and significant effect on private investment. Further, foreign exchange availability positively affects private investment. It is found that the policies adopted by the Government of Tanzania since 1986 have enhanced private investment in the economy. 
Therefore, given the above two studies, we there assert that inflation does not have positive and significant impact on infrastructural investment in the Nigerian economy. We represent our model as:

$\begin{array}{lll}\text { INFI } & =a+b \text { INFR }+\mu \ldots \ldots \ldots \ldots \ldots \ldots \ldots \ldots \ldots \ldots \ldots \ldots \ldots \ldots \ldots \\ \text { Where: } & \\ \text { INFI }= & \text { Infrastructural investment } \\ \text { INFR }= & \text { Inflation rate } \\ \mathrm{a} & = & \text { Constant of the equation } \\ \mathrm{b} & = & \text { Coefficient of the independent variable } \\ \mu & = & \text { Error Term }\end{array}$

In economics, the inflation rate is a measure of inflation, or the rate of increase of a price index such as the consumer price index. It is the percentage rate of change in price level over time, usually one year. The rate of decrease in the purchasing power of money is approximately equal. The rate is usually expressed in annualized terms, though measurement periods are not usually one year. In this study, the natural log of annualized inflation rate was adopted as the measure of inflation rate (Moshi and Kilindo, 1999)

Infrastructure is basic physical and organisational structures needed for the operation of a society or enterprises or the services and facilities necessary for an economy to function. It can be generally defined as the set of interconnected structural elements that provide framework supporting an entire structure of development. It is an important term for judging a country or region's development. The term typically refers to the technical structures that support a society, such as roads, water supply, sewers, electrical grids, telecommunications, and so forth, and can be defined as "the physical components of interrelated systems providing commodities and services essential to enable, sustain, or enhance societal living conditions Viewed functionally, infrastructure facilitates the production of goods and services, and also the distribution of finished products to markets. Again following the work of Moshi and Kilindo (1999), the total of infrastructural investment by government divided by gross domestic product was adopted as a measure of this proxy.

\subsection{Analysis}

Table 1 presents the quantum and ratio values of the proxies used to test hypothesis one from 1987 to 2011 . The gross domestic product of Nigeria in 1987 was N204, 806.5m and this rose to N219, 875.6m in 1988 indicating an increase of $7.4 \%$. The gross domestic product showed a consistent and gradual increase from year to year except in few years where there was a fall from the previous year values. It increased by $7.7 \%$ to N236, $729.6 \mathrm{~m}$ in 1989 and again increased by $13 \%$ to N267, 550m in 1990. In 1991, GDP fell by $0.8 \%$ to N265, 379.1m from N267, 550m in 1990. However, in 1992, it once again increased by $2.3 \%$ to $\mathrm{N} 271,365.5 \mathrm{~m}$. It rose by $1.3 \%, 0.2 \% 2.2 \% 4.4 \%, 2.8 \%$ and $2.9 \%$ respectively from 1993 , $1994,1995,1996.1997$ and 1998 . In 1999 , it rose by $0.4 \%$ to N312, $181.5 \mathrm{~m}$ and again by $5.4 \%$ and $8.4 \%$ in 2000 and 2001. In 2002, Nigeria's GDP increased by $21.3 \%$. In 2003 and 2004 , it again rose by $10.2 \%$ and $10.5 \%$ respectively. From 2005 to 2011, the growth rate of Nigeria's GDP maintained an average of $6.2 \%$.

The total infrastructural investment in Nigeria as revealed from table 1 reveals that the infrastructural investment from 1987 to 2008 similarly exhibited fluctuations. In 1987 it was N2, 159.7m but fell in 1988 to N2, 128.7m but, rose to N3, 926.3m in1989. In 1990 it was N3, 485.7m. In 1991, infrastructural investment fell to N3, 145.00m. It again fell in 1992 when it was N2, 336.7m and fell again in 1993 to N18, 344. 7m. However, increase in 1994 when it was N27, 102.8m and continued to increase until in 2000 when it fell from N323, 580.8m in 1999 to N111, 508.6m. Between 2001 and 2011 , there was fluctuation, the total infrastructural investment fell from the previous quantum value in 2002 (N215, 333.4m), 2003 (N97, 982.1m), 2006 (N262, 207.3m). In 2009 Infrastructural investment was N617,191.42m, in 2010, it rose to $\mathrm{N} 712,996.08 \mathrm{~m}$ and in 2011 it again rose to $\mathrm{N} 810,537.76 \mathrm{~m}$.

\section{Table 1 GDP Infrastructural Investment and Inflation Rate}

\begin{tabular}{|l|c|c|l|l|l|}
\hline Year & GDP (N,000m) & INFI(N,000m) & INFR (\%) & Log(infr) & infi/gdp \\
\hline 1987 & $204,806.50$ & $2,159.70$ & 9.51 & 0.978 & 0.011 \\
\hline 1988 & $219,875.60$ & $2,128.70$ & 60.43 & 1.781 & 0.01 \\
\hline 1989 & $236,729.60$ & $3,926.30$ & 45.88 & 1.662 & 0.017 \\
\hline 1990 & $267,550.00$ & $3,485.70$ & 3.03 & 0.481 & 0.013 \\
\hline 1991 & $265,379.10$ & $3,145.00$ & 20.06 & 1.302 & 0.012 \\
\hline 1992 & $271,365.50$ & $2,336.70$ & 51.24 & 1.71 & 0.009 \\
\hline 1993 & $274,833.30$ & $18,344.70$ & 60.17 & 1.779 & 0.067 \\
\hline
\end{tabular}




\begin{tabular}{|c|c|c|c|c|c|}
\hline Year & GDP $(\mathbf{N}, 000 \mathrm{~m})$ & INFI(N,000m) & INFR (\%) & Log(infr) & infi/gdp \\
\hline 1994 & $275,450.60$ & $27,102.80$ & 70.97 & 1.851 & 0.098 \\
\hline 1995 & $281,407.40$ & $43,149.20$ & 55.65 & 1.745 & 0.153 \\
\hline 1996 & $293,745.40$ & $117,829.10$ & 19.85 & 1.298 & 0.401 \\
\hline 1997 & $302,022.50$ & $169,613.10$ & 8.2 & 0.914 & 0.562 \\
\hline 1998 & $310,890.10$ & $200,861.90$ & 10.6 & 1.025 & 0.646 \\
\hline 1999 & $312,183.50$ & $323,580.80$ & 0.55 & -0.26 & 1.037 \\
\hline 2000 & $329,178.70$ & $111,508.60$ & 15.66 & 1.195 & 0.339 \\
\hline 2001 & $356,994.30$ & $259,757.80$ & 17.76 & 1.249 & 0.728 \\
\hline 2002 & $433,203.50$ & $215,333.40$ & 9.83 & 0.993 & 0.497 \\
\hline 2003 & $477,533.00$ & $97,982.10$ & 22.91 & 1.36 & 0.205 \\
\hline 2004 & $527,576.00$ & $167,721.80$ & 10.31 & 1.013 & 0.318 \\
\hline 2005 & $561,931.40$ & $265,034.70$ & 15.02 & 1.177 & 0.472 \\
\hline 2006 & $595,821.60$ & $262,207.30$ & 7.47 & 0.873 & 0.44 \\
\hline 2007 & $634,251.10$ & $367,900.00$ & 6.56 & 0.817 & 0.58 \\
\hline 2008 & $674,889.00$ & $504,400.00$ & 15.1 & 1.179 & 0.747 \\
\hline 2009 & $24,794,238.66$ & $617,191.42$ & 13.9 & 1.143 & 0.013 \\
\hline 2010 & $33,984,754.13$ & $712,996.08$ & 11.8 & 1.072 & 0.012 \\
\hline 2011 & $37,543,654.70$ & $810,537.76$ & 10.3 & 1.013 & 0.008 \\
\hline
\end{tabular}

\section{Source: CBN Statistical Bulletin (Various years)}

The inflation rate in Nigeria was also revealed in table 1. For most of the period under study, inflation rate has been on a double digit rate. The double digit rate was observed in 15 periods out of the 25period under study. This was observed in 1988, (60.43\%), 1989 (45.88\%), 1991 (20.06\%), 1992 (51.24\%), 1993 (60.17), 1994 (70.97), 1995 (55.65\%), 1996 (19.85\%), 1998 (10.6\%), 2000 (15.66), 2001 (17.76\%), 2003 (22.91\%), 2004 (10.31\%), 2005 (15.02\%), $2008(15.1 \%) 2009$ (13.9\%), 2010 (11.8\%) 2011 (10.3\%). Single digit was however observed in 1987 (9.51\%), 1990 (3.03\%), 1997(8.2\%), 1999 (0.55\%), 2002 (9.83\%), 2006 (7.47\%), and 2007 (6.56\%).

Figure 1 presents diagrammatically the ratio values of infrastructural investment and inflation rate from 1987 to 2011.

Figure 1 Infrastructural investment and inflation rate from 1987 to 2011

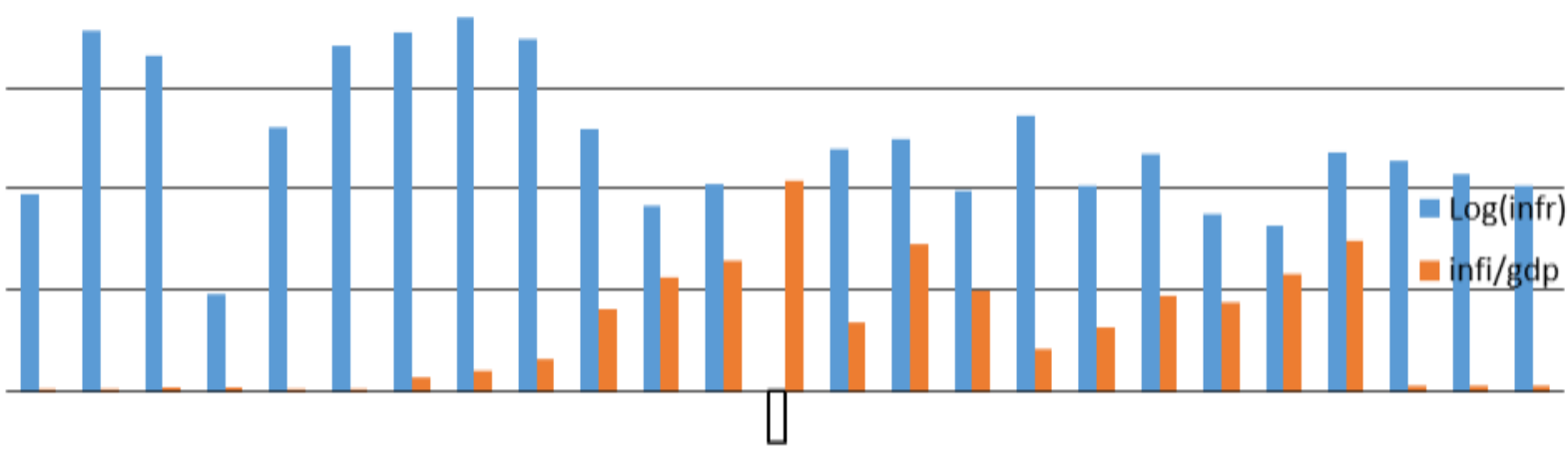

\section{Source: Researcher's Excel Computation}


Table 2: Analysis of Regression Result

Dependent Variable: INFIGDP

\begin{tabular}{lrlrr}
\multicolumn{1}{c}{ Variable } & Coefficient & Std. Error & t-Statistic & Prob. \\
\hline \hline \multicolumn{1}{c}{ LOGINF } & -0.385793 & 0.106089 & -3.636509 & 0.0016 \\
C & 0.792714 & 0.135843 & 5.835528 & 0.0000 \\
\hline \hline R-squared & 0.798029 & Mean dependent var & 0.334636 \\
Adjusted R-squared & 0.767931 & S.D. dependent var & 0.300000 \\
S.E. of regression & 0.238508 & Akaike info criterion & 0.057683 \\
Sum squared resid & 1.137725 & Schwarz criterion & 0.156869 \\
Log likelihood & 1.365487 & F-statistic & 13.22420 \\
Durbin-Watson stat & 0.853796 & Prob(F-statistic) & 0.001643 \\
\hline \hline
\end{tabular}

\section{Source: Researcher's E-view Result}

Model Equation infi $=0.793-0.386$ loginf +0.106

From table 2 above, the result indicates that inflation has negative and significant impact on the infrastructural investment in Nigeria (coefficient of inf $=-0.386$, t-value $=-3.637$ ). The Coefficient of determination $\left(R^{2}\right)$ is $79.8 \%$. This is very high indicating that the variation in the dependent variable (infrastructural investment) was $79.8 \%$ captured by changes in the independent variable (inflation rate). The variation was properly adjusted by the adjusted $R^{2}$ of $76.8 \%$. The Durbin Watson (d test statistic) was 0.854 which is less than the rule of thumb value of 2 indicating that there was no sign of autocorrelation.

\subsection{Conclusion and Recommendation}

From the data analysis, it shows that the impact of inflation rate on infrastructural investment was negative and significant in Nigeria. Looking at the years under study $(1987$ - 2011) it will be discovered that as inflation was double-digit investment in 15 years out of the 25yuears under study. Inflationary conditions imply that the general price level keeps increasing over time; and this instability in the general price level undermines the functions of money as a store of value, and discourages investment and growth. To appreciate the need to fight inflation, it is imperative to understand the implication of frequent price increases in the economic system of a nation. This implication includes discouragement of long term planning; reduction in savings and capital accumulation; reduction in investment and business growth; shift in the distribution of real income and consequent misallocation of resources; and creating uncertainty and distortion in the economy.

To avoid any of the above situations, monetary policy authorities must ensure that the general price level remains stable. This can be achieved by implementing policies that guard against inflation. Generally, high rate and volatility of inflation does not only make forecasting future more difficult, uncertainty regarding future inflation increases the risks associated with investment planning and thereby reduce the level of investment spending. Inflation uncertainty negatively affects foreign direct investment (FDI), delay investment decision and lowers investment. Positive economic growth is primarily a consequence of foreign rate of time-preference which invariably results in the increase of share of savings and investment to consumption and as well as declining rate of interest as witness in Nigeria. One important thing that emerges from this analysis is that the bulk of aggregate output growth has been driven by monetary inflation with consequent impact on investment through the medium of artificially lowered interest rate. We therefore, recommend that governm ent should stick to prudent economic policies avoid excessive money printing which inflation targeting would achieved via price stabilization and also promote investment climate in Nigeria.

\section{References}

1. Barro, R.J. (1991), "Economic growth in a cross section of countries" Quarterly Journal of Economics, 106(2):407-43

2. Bleaney, M.F. (1996), 'Macroeconomic stability, investment and growth in developing countries", Journal of Development Economics, 48(2):461-77

3. Cardoso, E. and Fishlow A. (1989), Latin America Economic Development 1950-1980, NBER Working Paper 3161

4. Cordon, W. M. (1990), "Macroeconomic policy and growth: some lessons of experience" Proceedings of the World Bank Annual Conference on Development Economics, World Bank, Washington, DC

5. De Gregorio, J. (1992a), "Economic growth in Latin America", Journal of Development Economics, 39(1):59-84 
6. De Gregorio, J. (1992b), "The effects of inflation on economic growth: lessons from Latin America", European Economic Review, 36(2-3):417-25

7. De Gregorio J (1993), 'Inflation taxation, and long-run growth", Journal of Monetary Economics, 31(3):271-98

8. Easterly, W. and Rebelo, S (1993), "Fiscal policy and economic growth: an empirical investigation", Journal of Monetary Economics, 32(3):417-58

9. Fischer, S., (1983), Inflation and Growth, NBER Working Paper 1235, National Bureau of Economic Research, New Delhi

10. Fischer, S. (1991), "Growth, macroeconomics and development", NBER Macroeconomics Annual, 6:329-64

11. Fischer, S. (1993), "Macroeconomics factors in growth" Paper presented at the World Bank Conference on How do national policies affect long-run growth?

12. Frenkel, J.A. and Khan, M.S. (1990), "Adjustment policies and economic development”, American Journal of Agricultural Economics, 72(3):815-20

13. Gokal, V and S. Hanif (2004), "Relationship between Inflation and Economic Growth" Economics Department of Reserve Bank of Fiji Working Paper 2004/04

14. Grier, K.B., and Tullock G. (1989), "An empirical analysis of cross-national economic growth 1951-80”, Journal of Monetary Economics, 24(2):259-76

15. Gylfason, T. (1991), "Inflation, growth and external debt: a view of the landscape", The World Economy, 14:27998

16. Helleistein, R. (1997), "The Impact of Inflation on Investment”, East European Regional Review; Vol. 7 No. 1

17. Kormendi, R.C. and Meguire, P.G (1985), "Macroeconomic determinants of growth: cross country evidence", Journal of Monetary Economics, 16(2):141-63

18. Levine, R. and D. Renelt, D. (1992), "A sensitivity analysis of cross-country growth regressions", American Economic Review, 82(4):942-63

19. Moshi, H.P.B and A.A.L Kilindo (1999), "The impact of government policy on macroeconomic variables: A case study of private investment in Tanzania", African Economic Research Consortium AERC Research Paper 89

20. Nwankwo, G.O., (1981), Financial Management, UK: Oxford University Press

21. Pindyck, R. and Solimano, A. (1993), "Economic instability and aggregate investment", NBER Macroeconomics Annual, MIT Press, Cambridge and London:259-303

22. Roubini, N. and Sala-i-Martin, X. (1992), "Financial repression and economic growth", Journal of Development Economics, 39(1):5-30

23. Serven, L. and Solimano, A., (1992), "Private investment and macroeconomic adjustment: a survey", TheWorld Bank Research Observer, 7(1):95-114 